\title{
of JURNAL \\ \# REKONSTRUKSI DAN ESTETIK \\ A Case Series : Hymenoplasty Based on The Type of The Tear or Cleft Preoperation Finding For Good Satisfaction Postoperative Result
}

\author{
Rianto Noviady Ramlia, Agus Santoso Budi ${ }^{*}$ \\ aDepartment of Plastic Reconstructive and Aesthetic Surgery, Faculty of Medicine Universitas Airlangga \\ *Corresponding author: Agus Santoso Budi - Department of Plastic Reconstructive and Aesthetic Surgery, \\ Faculty of Medicine Universitas Airlangga \\ Email address: agus_sbeyk@yahoo.com
}

ARTICLE INFO

Keywords:

Hymen

Hymenoplasty
ABSTRACT

Purpose: To describe our surgical hymenoplasty technique based on the type of the tear or cleft finding preoperative for satisfaction postoperative.

Patient and methods: Hymenoplasty was performed on 4 patient on January 2017 until March 2017, we found three patients with U-type, 1 patient with V-type. And we performed hymenoplasty which is to create a new surface raw, on the right and left cleft to be stiched, we use a rapid absorbable suture material, with horizontal mattress technique.

Results: No complications developed in the patients who had undergone hymenoplasty and all patients stated that the sexual intercourse they experienced was similar to the night of the initial experience.

Discussion : Our new apporach for hymenoplasty is a technique that has good results, and this is a good approach in doing hymenoplasty.
O ver centuries, virginity has been given social, religious and moral importance. It is widely believed as a state of a female who has never engaged in sexual intercourse, and her hymen is intact. Hymenoplasty for torn hymen is carried out not only for the sake of cultural and religious traditions but also for the social.1

The word 'hymen' refers to 'the god of wedding and wedding ceremonies', holding a torch in hand, who was the son of Dionysus and Aphrodite, known as 'Hymenaeus' in ancient Greek mythology. Hymen is a thin and fragile mucosal fold located 1-1.5 cm proximal to the vaginal introitus. Its function is not known. It may prevent the newborn from vaginal infections. Most cultures adopt it as a symbol of virginity. The hymen may be damaged in sexual intercourse as well as by masturbation, hand manipulations by the sexual partner,2 straddle trauma,3-6 physical examination, 5 motor accidents 7 or by the use of tampons.2 On the other hand, it has been reported that the hymen may not be injured during biking, riding, gymnastics or other sports activities. 8

Hymenoplasty is restoration of the hymen and hymenorrhaphy is re suturation of the hymen. However, these terms are generally used as synonyms. Little information exists in the literature concerning the surgical technique and results 
of hymenoplasty9. In some regions of the world, a woman can be required to undergo an inspection of the hymen by a gynecologist or another health provider to "certify" her virginity before marriage 10 . In other situations, women are expected to bleed at first marital coitus, with the sheets displayed to demonstrate her apparent virginity 10,11. Lack of confirmation of her chastity in either case can be life-threatening or life-altering. As such, it is understandable that physicians might indeed wish to assist women requesting hymenoplasty and legitimately consider that the procedure is medically indicated, satisfying the WHO concept of "health" as serving "physical, mental and social well-being" 12 in the circumstances and cultures within which individuals live. Given the available medical evidence, however, there are several professional and ethical problems associated with the idea that hymenoplasty will meet the needs of women who request this procedure .

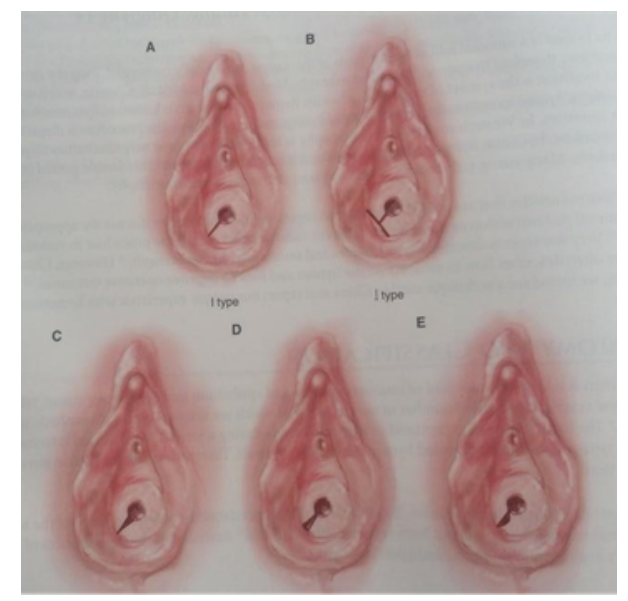

\section{METHOD}

This is a quasi experimental study in vivo with post test only group design. This study aims to find out and analyze platelet count alteration in post electrically-injured rats during acute and subacute phase. This study was conducted in Pharmacology and Biomedic Laboratory and Clinical Pathology

Laboratory, Faculty of Medicine Universitas Jember after ethical clearance approval from Faculty of Medicine Universitas Jember. All 24 white rats (Rattus novergicus, Wistar strain) age 10-16 weeks, weighed 250-320 grams were randomized into six groups. Based on report by McCann et al, they classify the shape of the tear, or cleft, into the following five type:

1. I type ; The two edges of the wound are well defined with no tissue deffect and are closely approximated.. The cleft has an I shape

2. $\perp$ type: No tissue defect is present. The laceration extends from the edge to the base of the hymen and continues along the base bilaterally. All edges of the wound are closely approximated. The cleft has a $\perp$ shape.

3. V type : A tissue defect is present near the free edge of the hymen. The two edges of the cleft are approximated or connected at the base of the hymen and separated at the free edge. The cleft has a $V$ shape.

4. $\Delta$ type : A tissue defect is present near the base of the hymen. The two edges of the cleft are close together at the free edge and farther apart at the base of the hymen, the cleft has a $\Delta$ shape

5. U type : A tissue defect is present between the two edges of the cleft. The edges are separated from the free edge to the base of the hymen. The cleft has a U shape.

\section{CASE REPORT}

We do hymenoplasty based on Mc Cann classification.

\section{Case 1}

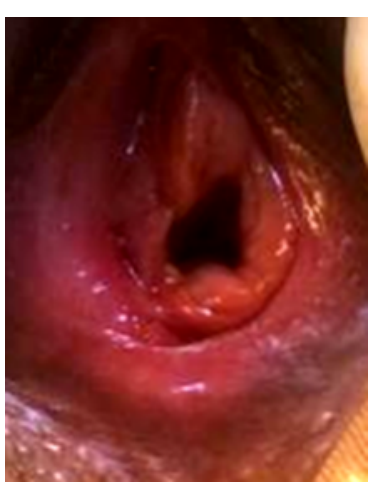

Pre Operation

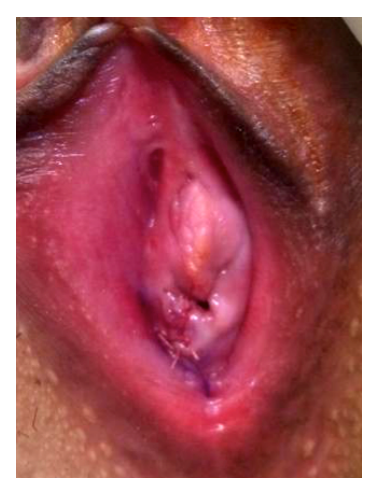

Post Operation 
Female, 24 yo, had U type on 7 o'clock: atissue defect is present between the two edges of the cleft. The edges are separated from the free edge to the base of the hymen. The cleft has a U shape.

\section{Case 2}

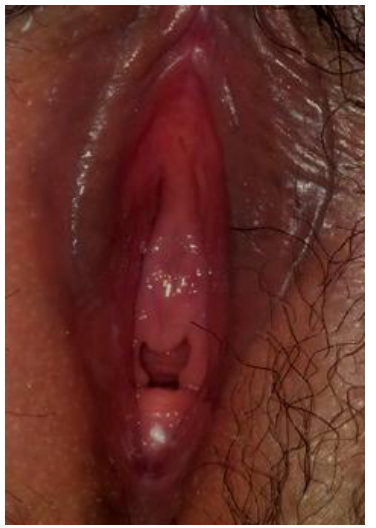

Pre Operation

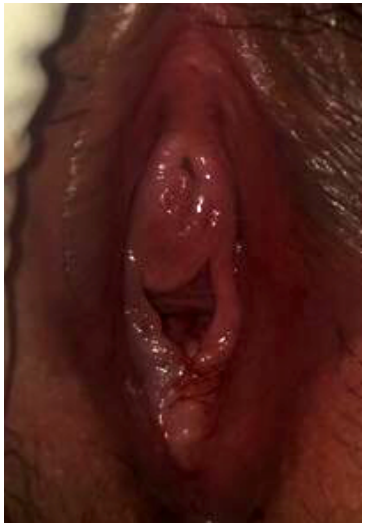

Post Operation
Female, 26 yo, had $U$ type 6 o'clock: a tissue defect is present between the two edges of the cleft. The edges are separated from the free edge to the base of the hymen. The cleft has a U shape.

\section{Case 3}

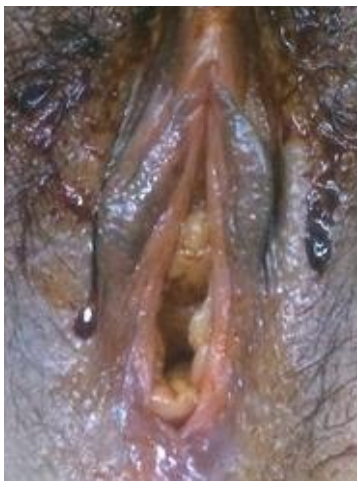

Pre Operation

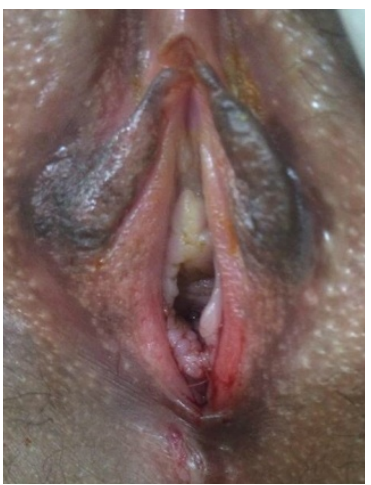

Post Operation
Female, 25 yo, had U type on 5 o'clock: atissue defect is present between the two edges of the cleft. The edges are separated from the free edge to the base of the hymen. The cleft has a U shape.

\section{Conclusion}

There are some points that must be considered in order to obtain good results hymenoplasty

- A comprehensive preoperatif consultation is essential to ensure patient and surgeon satisfaction postoperatively

- Preoperative evaluation of the hymenal tissue, especially the shape of the cleft, is the basis on which a surgical technique is selected. The surgical technique is determining factor for a succesful hymenorrhaphy.

- Only one to three cleft are repaired in one ruptured hymen, because as more cleft are closed, wound tension increases.

- Because the blood supply of the hymen is decreased compared with that of surrounding tissues, repeated clamping and suturing is avoided, and minimal suturing is performed.

- When defects are created on the edge of the cleft, only epithelium is removed. Defect margins should not be undermined to protect the blood supply.

- Only the mucosa and minimal submucous tissue are sutured during wound closure.

- The lower wound tension, the better result. Therefore trensposititionflaps are helpful for $\mathrm{V}, \Delta$, and $\mathrm{V}$ type hymenal clefts.

- The reconstructed hymenal opening ussualy is $8 \mathrm{~mm}$ in diameter (and not less than $5 \mathrm{~mm}$ ) to allow menstrual blood outflow.

- Absorbable suture should be used, because suture removal can tear weakly healed tissue.

\section{References}

1. Hemant A. Saraiya. Surgical revirgination: Four vaginal mucosal flaps for reconstruction of a hymen. Indian J Plast Surg. 2015 May-Aug; 48(2): 192-195.

2. Goodyear-Smith FA, Laidlaw TM. Can tampon use cause hymen changes in girls who have not had sexual intercourse? A review of the literature. Forensic Sci Int. 1998;94(1-2):14753.

3. West R, Davies A, Fenton T. Accidental vulval injuries in childhood. BMJ. 1989;298(6679):1002-3. 
4. Bond GR, Dowd MD, Landsman I, Rimsza M. Unintentional perineal injury in prepubescent girls: a multicenter, prospective report of 56 girls. Pediatrics. 1995;95(5):628-31

5. Pokorny SF, Pokorny WJ, Kramer W. Acute genital injury in the prepubertal girl. Am J Obstet Gynecol. 1992;166(5):1461-6.

6. Dowd MD, Fitzmaurice L, Knapp JF, Mooney D. The interpretation of urogenital fndings in children with straddle injuries. J Pediatr Surg. 1994;29(1):7-10.

7. Boos SC. Accidental hymenal injury mimicking sexual trauma.

8. Pediatrics. 1999;103(6 Pt1):1287-90.

9. Merritt DF. Genital trauma in children and adolescents. Clin Obstet Gynecol. 2008;51(2):237-48.

10. Dağhan Işık, Coşkun Erçel, Rohat Kutlay, Recep Anlatıcl. Re-Virginitation : Hymenoplasty. Turk Plast Surg 2011;19 (1)

11. Wei S-Y, Li Q, Li S-K, Zhou C-D, Li F-Y, Zhou Y. A new surgical technique of hymenoplasty. Int J Gynecol Obstet 2015;130(1):14-8

12. Hegazy AA, Al-Rukban MO. Hymen: facts and conceptions. theHealth 2012;3(4):

13. 109-15.

14. World Health Organization. Constitution of the World Health Organization. http://

15. www.who.int/governance/eb/who_constituti on_en.pdf. 